\title{
Incompetence of the duty to labour rules in resolving labour rights conflicts
}

\section{Opinion}

Whether the duty to labour rule is competent to resolve conflicts over labour rights largely depends on the role of this duty in major human rights standards. The fact that the duty to labour is found among the restricted exceptions and not within the basic principle-that is, the right to labour-suggests its incompetence as a tool in resolving rights conflicts at any level or in any context. This paper will briefly analysis the prohibition of forced labour of the International law, and some of the exceptions according to the ICCPR. As a member of the ICCPR, although China made big progress in the elimination of forced labour, there is still a long way to go pertaining to the duty to labour rule both in legislation and judicial enforcement.

\section{General introduction}

International human rights law prohibits slavery and servitude without derogations. International human rights law generally prohibits forced labour but allows for several exceptions to this rule. These exceptions clarify when compulsory work or service is not forced labour rather than saying that under certain circumstances, forced labour may be permissible. However, despite the fact that compulsory work is classified separately from forced labour, permissible forms of compulsory work may nonetheless violate international human rights obligations: for example, when compulsory work or service is equivalent in practice to forced labour or is assigned in a discriminatory manner. Moreover, a regime of compulsory labour is fundamentally incompatible with the right to work as an economic right because it prevents workers from seeking out the most financially rewarding opportunities available. Permitting the imposition of compulsory work or service would create an implied exception to the right to work and would remove protections from labourers that they would otherwise have enjoyed. Workers should be protected from exploitation by ensuring that compulsory labour occurs under just and favourable conditions, particularly in the private sector.

The international nature of labour law, unlike China's domestic interpretation of labour, is not a duty to perform but a right to freely choose. With respect to international human rights standards on labour, China is a party to the International Convenant on Economic, Social and Cultural Rights (ICESCR), the Convention on the Rights of the Child (CRC), the Convention against Torture and Other Cruel, Inhuman or Degrading Treatment or Punishment (CAT), the Equal Remuneration Convention, the Remuneration Policy Convention and the Convention concerning the Prohibition and Immediate Action for the Elimination of the Worst Forms of Child Labour and is obliged to faithfully fulfil the relevant obligations on the right to labour as set forth in these treaties. Specifically, China is obligated to prohibit those under the age of 18 from being subjected to forced labour by the CRC and Convention Concerning the Prohibition and Immediate Action for the Elimination of the Worst Forms of Child Labour (ILO182). China is also obligated to prohibit torture and cruel, inhuman or degrading

\author{
Volume 7 Issue 4 - 2019
}

\author{
$\mathrm{Na}$ Jiang,' Rong HAN, ${ }^{2}$ Yue WANG ${ }^{2}$ \\ 'Associate Professor of Law, Beijing Normal University, China \\ 'LLM candidate, Law School, Beijing Normal University, China \\ Correspondence: $\mathrm{Na}$ Jiang, Associate Professor of Law, Beijing \\ Normal University, China-100875, Email na.jiang@bnu.edu.cn \\ Received: June 17, 2019| Published: July 10, 2019
}

treatment or punishment without derogations or exceptions in any circumstances under the CAT (and under the CRC for children).

China's obligations also contain protections for labourers, such as the rights to non-discrimination, to equality, to freely choose one's occupation and to just and favourable working conditions pursuant to the ICESCR, ILO100 and ILO122. These treaty obligations prohibit forced labour and related human rights breaches. After China ratifies the ICCPR, the nation will undertake further treaty obligations prohibiting forced labour and individual or systematic breaches of human rights. ICCPR Article 8(3) prohibits forced labour but provides for permissible forms of compulsory work or service, including hard labour as punishment for a crime; work in detention and military or national service; duties in emergency; and ordinary civic obligations. The ICCPR provides few details on the prohibition of forced labour, leaving further interpretation to be performed with reference to other relevant instruments. For instance, the Forced Labour Convention (ILO29), the Slavery, Servitude, Forced Labour and Similar Institutions and Practices Convention of 1926 and the ILO105 appear to prohibit compulsory work or service for the benefit of the private sector, clarifying the ICCPR's prohibition of forced labour (and servitude). These provisions include Article 8(3)(a), which permits derogations in certain circumstances as part of the definition of forced labour under five primary types of duty cases.

\section{The exceptions of compulsory work in ICCPR}

Article 8(3)(b) states that the prohibition of forced labour "shall not be held to preclude, in countries where imprisonment with hard labour may be imposed as a punishment for a crime, the performance of hard labour in pursuance of a sentence to such punishment by a competent court." Hence, criminally punitive hard labour seems to be a legally permissible form of compulsory work or service and not merely an exception to forced labour. This formulation seems reasonable given that courts in some States commonly impose sentences of imprisonment with hard labour. However, from a legal perspective, there is no difference between not precluding criminally punitive forced labour and an exception to a general prohibition of forced labour. Although article 8(3)(b) allows for imprisonment with hard labour, rendered by a judgement of a competent court to be imposed 
as punishment for a statutorily defined crime, several requirements and procedural guarantees should be noted. First, the language of Article 8(3)(b) suggests that its provisions apply to hard labour but not to light labour. "Classical forms of forced labour in work colonies or camps" are good examples of hard labour. Because hard labour will rarely be required for minor offences, the forced labour provisions of Article 8(3)(b) appear to be imposed for serious offences only.

Article 8(3)(b) appears to be limited by ICCPR Article 10(3), which states that penitentiary systems shall "comprise treatment of prisoners the essential aim of which shall be their reformation and social rehabilitation." This language appears to leave no opening for hard labour as criminal punishment. Another restriction on Article $8(3)(b)$ is that punishments of hard labour may be imposed only for statutorily defined crimes. Considering that such crimes tend to be serious offences, this language appears to exclude light offences, which are mainly punishable by administrative punishments, such as a fine. Finally, punishments of hard labour may only be imposed by a competent court under a law explicitly stipulating such punishment. Competent courts should provide suspects with all judicial guarantees and should not be mere administrative bodies. Hence, hard labour may only be imposed as part of a criminal conviction by a competent court based on laws expressly providing for it and explicitly provided for by the sentence issued by the court. Article 8(3)(c) precludes four categories of compulsory work or service from the term "forced or compulsory labour".

The first category is any "work or service ... normally required of a person who is under detention in consequence of a lawful order of a court, or of a person during conditional release from such detention" without being precluded by Article 8(3)(b). Article 8(3)(c) (i) addresses routine work that persons under detention must perform. Unlike the hard labour referenced in Article 8(3)(b), such work is limited to routine work or service "normally required of a person" during detention or during "conditional release from such detention", such as cleaning cells or preparing food. Detention covered by Article $8(3)$ (b) broadly includes pre-trial detention for grounds "contained in the court decision" and "other forms of judicially imposed custody pursuant to Article 9". Compelling pre-trial detainees to work seems to be possible only "in consequence of lawful order of a court". This requirement means that a lawful court order must expressly provide for the work or service as a punishment, similar to the "in pursuance of a sentence" requirement in Article 8(3)(b). This phrasing leaves no room for an administrative authority to make specific directives concerning such work without explicit reliance on a lawful court for legal justification.

Article 9 of the ICCPR prohibits all forms of arbitrary arrest or detention, except "on such grounds and in accordance with such procedure as are established by law". Thus, Article 9 appears to allow "judicially imposed custody" rendered by a competent court pursuant to the law. Article 9 also requires that lawful administrative detention must be directly reviewed by a competent court in the way of proceedings. According Article 10(3), prison labour must have the essential aim of the "reformation and social rehabilitation" of detainees. Prisoners under conditional release appear to benefit from the same protections. Hence, the routine work referred to in Article $8(3)(c)(i)$ must be designed to promote the social rehabilitation of persons undergoing detention or those on conditional release from it. Moreover, the second category of exception contained in Article 8(3) (c)(ii) of the ICCPR is any "service of a military character and, in countries where conscientious objection" is recognised, "any national service required by law of conscientious objectors".

Exceptions also apply in circumstances where any service is "exacted in cases of emergency or calamity threatening the life or well-being of the community". Article 8(3)(c)(iii) addresses duties in the event of all emergencies or calamities regardless of whether they are national or local in scope. The ICCPR does not provide an explicit list of such emergencies or calamities, but Article 2(2)(d) of ILO29 implies that this list includes disasters such as wars, fires, floods, famines, earthquakes, violent epidemics or epizootic diseases and invasions by animal, insect or vegetable pests. The fourth exception, found in Article 8(3)(c)(iv) of the ICCPR, is any "work or service which forms part of normal civil obligations". These "normal civil obligations" appear to refer to such forced labour that is absolutely necessary to fulfil State functions and that cannot to be accomplished in a non-forcible manner, including both professional duties and most traditional civic obligations. However, in China, most traditional obligations are likely to be related to emergencies or calamities and thus would be covered by Article 8(3)(c)(iii).

Some other ICCPR provisions, apart from Article 8(3), appear to relate to the prohibition of forced labour. Specifically, Article 9 guarantees "the right to liberty and security of person", with a series of human rights procedural safeguards to restrict the deprivation of personal liberty and security. Article 9(1) requires the principles of legality and prohibition of arbitrariness; Article 9(2) addresses the right to be informed of one's right to be protected from forced labour; Article 9(3) addresses special rights for those in detention; Article 9(4) requires anyone "deprived of his liberty by arrest or detention" to be granted the right to have the detention decided in court without delay, allowing for only courts to decide what work a detainee must perform. This article also stipulates a victim's right to compensation after unlawful arrest or detention. In addition, Article 10 addresses the right of detainees to be treated with the humanity and dignity essential to the reformation and social rehabilitation of prisoners in penitentiary systems, and Article 14 details procedural guarantees in trials that also apply to China's Reform through Labour programme involving labour duties.

\section{Suggestions to the reform of the law in China}

Based on the above analysis, the labour law and other law related to hard labour and such like in China can make the following revisions to perfect the duty to labour rule in addressing labour rights conflicts. First of all, there is a need to provide clearly in law that labour is a right to choose in freedom to in line with the international standard. In the case of imposing compulsory work, the situation in which the rights of workers should be fulfilled and protected. Workers should not be biased in respect of equivalent rewards and safety working environment. In addition, given the protection of the juniors, children under the age of 18 shall not be exposure to force labour banned in CRC and ILO182 in which China is a member. Secondly, in no circumstance should the law allow the compulsory work in private sector. The exception of derogation pertaining to forced labour should be strictly limited to criminally punitive hard labour by a competent court according to the law. For example, the criminal code of China can provide the specific form of hard labour which is not in breach of ICCPR Article 8(3)(b) and Article 10(3). That is to say, the administrative authorities shall not impose hard labour to detainee in the absence of permission of the court. 
It is glad to know that the regulation of re-education through laboring in China was abolished in 2013. However, there is still some room to improve as to the ritual work or service of the prisoners who were sentenced to hard labour, which should be targeted at reeducation and rehabilitation instead of inhuman treatment in contrary to the obligations provided in CAT. As to the other exceptions of the compulsory labour, like any service of a military character or any national service required by law of conscientious objectors or any service resulted from emergencies or these "normal civil obligations", it is necessary for China to make more specific clarifications to these circumstance since the law of China just focused on the emergencies. Also, in the situation of natural disaster or other national emergencies, forced labour is only allowed in the condition of necessary and without any other better non-forcible alternatives. Therefore, the exceptions to the hard labour are only allowed under the specific articulation of the law and authorisation by the court from the perspective of human rights protection.

\section{Conclusion}

In conclusion, the duty to labour forbids forced or compulsory labour on the whole according to the international human rights standards, while allow some exceptions provided that the law clarified the requirements and procedures of the application. At the same time, imposing of compulsory is no way of meaning the other rights of prisoners such as the right to liberty and security of person, right to compensation resulting from unlawful arrest or detention and corresponding procedural guarantees are deprived. Thus, just as stated in the Article 2 of the Criminal Procedure Law of the People's Republic of China, the law-makers of China should always bear in mind that respecting and protecting human rights is one of the objectives of the law. China as a member the ICCPR should improve the incompetence of the duty to labour rule for the sake of human rights protection and set a good example to other countries.

\section{Acknowledgments}

None.

\section{Conflicts of interest}

The author declares that there are no conflicts of interest. 